\title{
Zbigniew Gruszka*
}

(iD) https://orcid.org/0000-0002-7834-3893

\section{Portal społecznościowy jako narzędzie do promowania informacji regionalnych - na przykładzie profili Facebook TVP Łódź, Radia Łódź i „Expressu \|lustrowanego"}

Celem autora była ocena działań na profilach Facebook trzech redakcji mediów regionalnych - TVP 3 Łódź, Radia Łódź oraz dziennika „Express Ilustrowany” w zakresie umieszczania lokalnych i regionalnych informacji oraz próba ilościowego określenia i porównania tej działalności. Zastosowano analizę zawartości profilu na Facebooku, którą przeprowadzono w ciągu jednego miesiąca (1 marca-31 marca 2018 roku).

Słowa kluczowe: media społecznościowe, informacje regionalne, promocja, portal spotecznościowy

* Dr, Uniwersytet Łódzki, Wydział Filologiczny, Katedra Informatologii i Bibliologii, ul. Pomorska 171/173, 90-236 Łódź; e-mail: zbigniew.gruszka@uni.lodz.pl 
Obecność mediów regionalnych w mediach społecznościowych stanowi interesujące zjawisko z zakresu konwergencji mediów ${ }^{1}$, polegające na dostosowaniu proponowanej oferty medialnej do wciąż wzrastających oczekiwań odbiorców, jak również umożliwiające jej personalizację. Nie bez znaczenia jest także możliwość większej niż w przypadku tradycyjnych mediów interakcji z odbiorcami, polegającej na stworzeniu przestrzeni cyfrowej do dzielenia się komentarzami, udostępniania i oceniania postów za pośrednictwem dostępnej na Facebooku skali.

Aktywność mediów regionalnych w przestrzeni cyfrowej stanowi przykład inbound marketingu - marketingu przychodzącego - przeciwstawnego do jego odpowiednika o nazwie outbound marketing polegającego głównie na promocji i reklamie. Angażowanie użytkowników i współpraca, budowanie wspólnoty i współtworzenie treści, a także otwartość - stanowiące według Nilofera Merchanta dystynktywne elementy ery społeczności ${ }^{2}$ - mają ostatecznie posłużyć do zaangażowania klienta w działania marketingowe i do wzrostu lojalności wobec marki ${ }^{3}$.

Badanie mediów regionalnych, będące $\mathrm{w}$ obszarze zainteresowań prasoznawców i mediologów, jest równie interesujące z informatologicznego punktu widzenia. Umożliwia bowiem przeanalizowanie zaobserwowanych mechanizmów związanych z zarządzaniem publikowaną informacją, określenie stopnia zaangażowania uczestników, jak również udzielenie odpowiedzi na pytanie, jak powinna być projektowana informacja medialna w przestrzeni Internetu społecznościowego, by spotkała się z reakcją użytkowników serwisu społecznościowego Facebook.

Celem autora pracy jest poznanie aktywności redakcji profili trzech łódzkich mediów regionalnych - stacji telewizyjnej TVP 3 Łódź, radiowej Radia Łódź i dziennika „Express Ilustrowany” - w przestrzeni platformy Facebook ${ }^{4}$ w szczególności

$1 \mathrm{Na}$ temat konwergencji wybranych mediów zob.: J. Bogdańska, Między prasa a cyberprzestrzenią. Analiza porównawcza gazety i serwisu www na przykładzie „Dziennika Łódzkiego”, „Acta Universitatis Lodziensis. Folia Litteraria Polonica" 2016, nr 2(32), s. 149-165; V. Wejs-Milewska, Współczesne radio - pytanie o tożsamość, „Acta Universitatis Lodziensis. Folia Litteraria Polonica" 2017, nr 1(39), s. 23-30.

2 A. Łaszkiewicz, Media społecznościowe i ich potencjał w generowaniu wartości dla organizacji, „Acta Universitatis Lodziensis. Folia Oeconomica” 2013, nr 287, s. 159-160; S. Kuczamer-Kłopotowska, Rola mediów społecznościowych w komunikacji pokolenia $Y$, „Handel Wewnętrzny" 2016, nr 3(362), s. 216-227, 222.

3 D. Zys, Inbound marketing - strategia przyszłości, https://sprawnymarketing.pl/inbound-marketing-strategia-przyszlosci/ [dostęp: 27.04.2018]; szerzej: K. Stopczyńska, Zarządzanie wizerunkiem firmy przy wykorzystaniu Inbound marketingu na przykładzie fan page, „Acta Universitatis Lodziensis. Folia Oeconomica" 2013, nr 287, s. 181-191.

4 Express Ilustrowany, https://www.facebook.com/Expressllustrowany/ [dostęp: 3.04.2018]; Radio Łódź, https://www.facebook.com/RadioLodz/ [dostęp: 3.04.2018]; TVP 3 Łódź, https:// www.facebook.com/tvplodz/ [dostęp: 3.04.2018]. 
w zakresie zamieszczania na profilach informacji lokalnych i regionalnych oraz próba kwantyfikacji i porównania tejże aktywności pomiędzy poszczególnymi profilami. Dla oceny odbioru materiałów umieszczanych w sieci scharakteryzowano częstotliwości i rodzaj treści umieszczanych na profilach, opisano najczęściej komentowane i udostępniane treści, jak również te, w przypadku których najczęściej klikano przycisk „lubię to”.

Przeprowadzona analiza dotyczy zawartości merytorycznej i kwantyfikacji postów na profilach społecznościowych trzech różnych mediów regionalnych. Zastosowano metodę badawczą polegającą na analizie zawartości profili w serwisie Facebook wspomnianych trzech mediów regionalnych na przestrzeni jednego miesiąca (1 marca - 31 marca 2018 roku) z wykorzystaniem konta w serwisie społecznościowym Facebook. Została również wykorzystana metoda porównawcza.

Wokół trzech portali zbudowały się różne społeczności internetowe (wirtualne, e-społeczności). Społeczność internetową rozumiem za przywołanym przez Agnieszkę Smalec Manuelem Castellsem, według którego jest to: „[...] samodefiniująca się, elektroniczna sieć interaktywnej komunikacji, zorganizowana wokół podzielanych zainteresowań lub celów, chociaż niekiedy komunikacja staje się celem samym w sobie"s.

Największą społeczność internetową zbudowali prowadzący profil „Expressu Ilustrowanego" - było to ponad 65,5 tys. osób. Czterokrotnie mniejszą społecznością dysponuje profil Radia Łódź (około 15 tys.), a dziesięciokrotnie mniejszą od „Expressu” - TVP 3 Łódź (prawie 7 tys.). Liczba obserwujących profile, a więc wyrażających zgodę na otrzymywanie od nich publikowanych treści była nieco niższa do liczby polubień.

Twórcy profili oferują dodatkowe funkcjonalności rozszerzające dostęp do publikowanych treści, takie jak możliwość oglądania on-line (TVP 3 Łódź), dostęp do konta Instagram i Youtube Radia Łódź czy do sklepu „Expressu Ilustrowanego”. $\mathrm{Z}$ trzech profili jedynie redakcja dziennika nie przygotowała opisu swojej działalności w serwisie Facebook (por. Tabela 1).

5 M. Castells, Społeczeństwo sieci, przeł. Mirosława Marody, Wydawnictwo Naukowe PWN, Warszawa 2008, s. 62. Cyt. za: A. Smalec, Rola społeczności internetowych w komunikacji marketingowej, „Ekonomiczne Problemy Usług” 2010, nr 55, s. 582. 
Tabela 1. Charakterystyka ogólna profili TVP Łódź, Radia Łódź i „Expressu llustrowanego” w serwisie społecznościowym Facebook

\begin{tabular}{|l|c|c|c|}
\cline { 2 - 4 } \multicolumn{1}{c|}{} & TVP 3 Łódź & Radio Łódź & "Express llustrowany” \\
\hline Liczba polubień & 6849 & 15160 & 65488 \\
\hline $\begin{array}{l}\text { Liczba } \\
\text { obserwujących }\end{array}$ & 6765 & 14736 & 63822 \\
\hline Funkcjonalności & Oglądaj nas online! & $\begin{array}{c}\text { Instagram, Youtube } \\
\text { Radia tódź }\end{array}$ & Sklep \\
\hline Opis & $\begin{array}{c}\text { Firma nadająca } \\
\text { i produkująca programy } \\
\text { telewizyjne w: tódź }\end{array}$ & Stacja radiowa w: tódź \\
\hline
\end{tabular}

Źródło: opracowanie własne. Stan na 3.04.2018.

\section{Analiza liczbowa}

W poddanym analizie okresie najwięcej postów na profilu społecznościowym w serwisie Facebook opublikowała redakcja „Expressu Ilustrowanego” (327), a następnie Radia Łódź (302). Znacznie mniejszą aktywnością wykazała się redakcja profilu TVP Łódź, która zamieściła 159 postów (zob. Wykres 1). Jak wynika z dalszych analiz, aktywność redakcji na profilu w zakresie publikowanych postów wpływa, choć niedecydująco, na rozmiar budowanej wokół profilu społeczności cyfrowej.

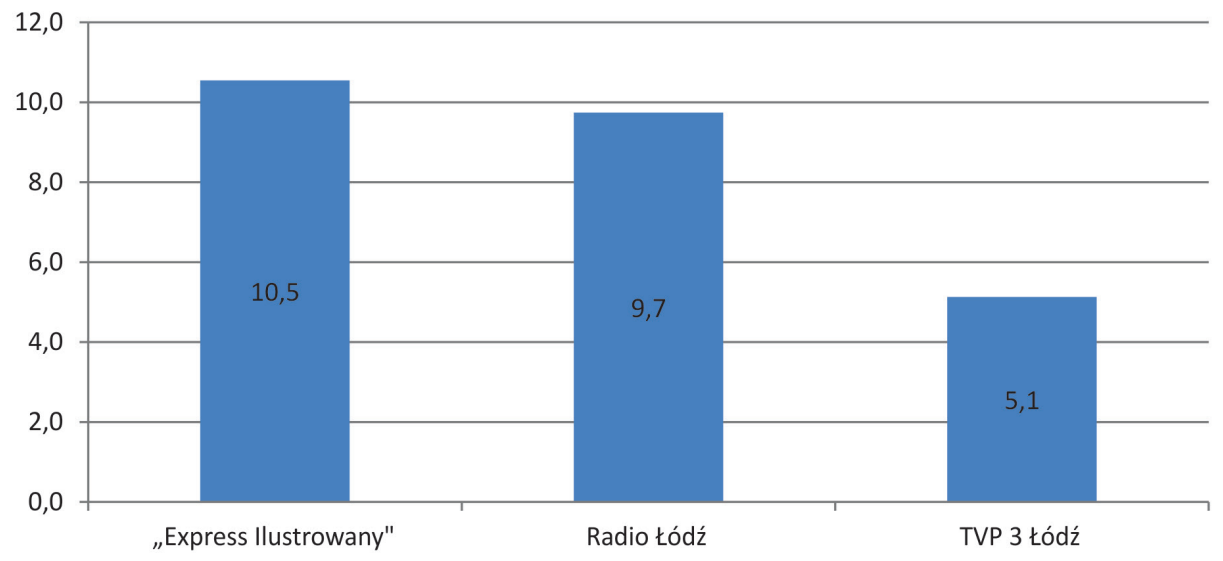

Wykres 1. Liczba opublikowanych postów w badanym okresie Źródło: opracowanie własne. Stan na 3.04.2018. 
Średnia dzienna aktywność w liczbie publikowanych postów była zbliżona w przypadku redakcji „Expressu Ilustrowanego” (10,5) i Radia Łódź $(9,7)$ - w obu przypadkach oscylowała wokół liczby 10. Połowę mniej postów dziennie $(5,1)$ zamieścili redaktorzy profilu społecznościowego TVP Łódź (Wykres 2).

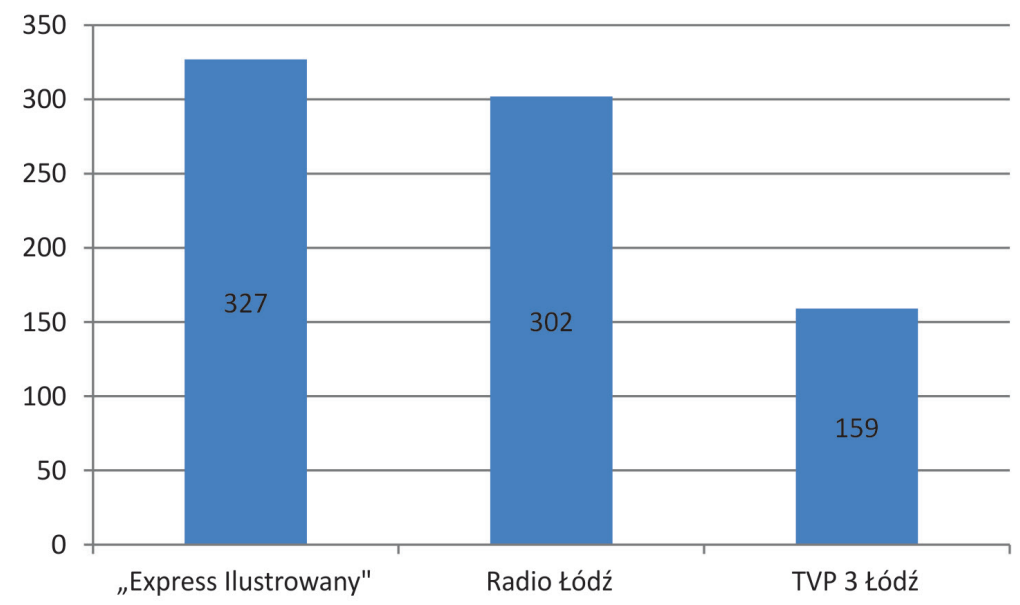

Wykres 2. Średnia dzienna liczba postów

Źródło: opracowanie własne. Stan na 3.04.2018.

Największa aktywność w liczbie publikowanych postów przypadła na godziny popołudniowe i wieczorne. Wzmożoną aktywnością charakteryzowała się w szczególności redakcja „Expressu Ilustrowanego”, publikując najwięcej postów w godzinach 15.00-17.59 oraz 18:00-20:59, jak również w godzinach przedpołudniowych (9:00-11:59). Szczytowy moment aktywności redakcji profilu Radia Łódź przypadł na godziny 12:00-14:59 oraz 18:00-20:59.

Osoby odpowiadające za profil TVP Łódź najczęściej publikowały posty wieczorem; znaczna aktywność przypadła na godziny 18:00-20:59. Mniejszą aktywność w przypadku wszystkich trzech profili wykazano w przypadku godzin porannych (6:00-8:59) i nocnych (21:00-23:59) z zastrzeżeniem, że redakcja TVP Łódź nie publikowała postów w godzinach porannych. Nikt oprócz prowadzących profil Radia Łódź nie zamieszczał w badanym okresie informacji w godzinach o:00-5:59. Godzin publikacji postów nie udało się ustalić w przypadku 15 postów profilu „Expressu Ilustrowanego", 31 postów profilu Radia Łódź oraz 16 postów profilu TVP Łódź (por. Wykres 3 i Tabela 2). 


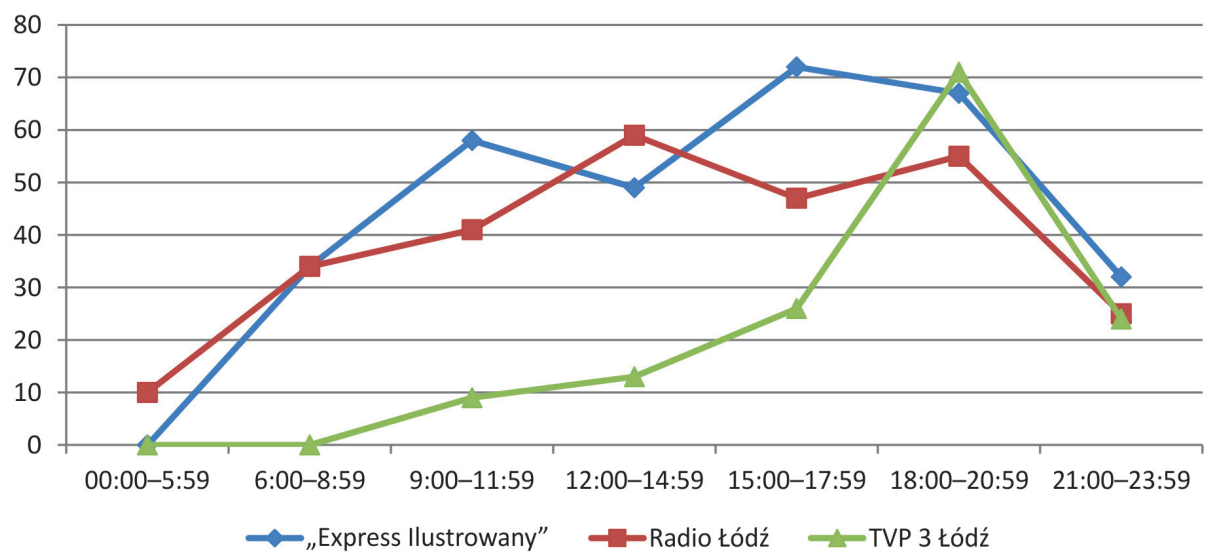

Wykres. 3. Ilustracja graficzna przedziałów czasowych publikacji postów na profilach Facebook „Expressu llustrowanego”, Radia Łódź i TVP 3 Łódź

Źródło: opracowanie własne. Stan na 3.04.2018.

Tabela 2. Ilustracja liczbowa przedziałów czasowych publikacji postów na profilach Facebook „Expressu llustrowanego”, Radia Łódź i TVP 3 Łódź

\begin{tabular}{|c|c|c|c|}
\hline Przedział godzinowy & „Express Ilustrowany” & Radio Łódź & TVP 3 Łódź \\
\hline 00:00-5:59 & 0 & 10 & 0 \\
\hline 6:00-8:59 & 34 & 34 & 0 \\
\hline 9:00-11:59 & 58 & 41 & 9 \\
\hline 12:00-14:59 & 49 & 59 & 13 \\
\hline 15:00-17:59 & 72 & 47 & 26 \\
\hline 18:00-20:59 & 67 & 55 & 71 \\
\hline $21: 00-23: 59$ & 32 & 25 & 24 \\
\hline bd. & 15 & 31 & 16 \\
\hline Suma & 327 & 302 & 159 \\
\hline
\end{tabular}

Źródło: opracowanie własne. Stan na 3.04.2018.

Łącznie w badanym okresie (31 dni) najwięcej reakcji odnotowano na profilu „Expressu Ilustrowanego”. Internauci posty profilu „Express Ilustrowany” polubili 9756 razy, profilu Radia Łódź - 1857 razy, natomiast profilu TVP 3 Łódź - 864 razy. „Express” zwyciężył również w kategorii liczby komentarzy i udostępnień (por. Tabela 3). Na tej podstawie można uznać, że najskuteczniej - spośród wszystkich przebadanych stron - angażuje internautów do reagowania społecznościowego na treści publikowane przez redakcję na profilu. 
W zestawieniu najniższe liczby dotyczące polubień, komentarzy i udostępnień osiągnął profil „TVP 3 Łódź”.

Tabela 3. Łączna liczba polubień, komentarzy i udostępnień na profilach „Expressu llustrowanego”, Radia Łódź i TVP 3 Łódź w marcu 2018 roku

\begin{tabular}{|l|c|c|c|}
\cline { 2 - 4 } \multicolumn{1}{c|}{} & „Express Ilustrowany” & Radio Łódź & TVP 3 Łódź \\
\hline Łączna liczba polubień & 9756 & 1857 & 864 \\
\hline Łączna liczba komentarzy & 4166 & 491 & 60 \\
\hline Łączna liczba udostępnień & 2928 & 189 & 229 \\
\hline
\end{tabular}

Źródło: opracowanie własne. Stan na 3.04.2018.

Wobec braku danych dotyczących liczby wyświetleń postów na wszystkich trzech badanych profilach trudno ustosunkować się do publikowanych przez redaktorów profilu $\mathrm{TVP}_{3}$ Łódź informacji na temat liczby wyświetleń materiałów audiowizualnych. Łącznie na 159 postów aż 114 (tj. 72\%) zawierało materiał audiowizualny (plik wideo reportażu, fragment Łódzkich Wiadomości Dnia, promocja programu). Analiza liczby wyświetleń tychże materiałów unaocznia, że jedynie w przypadku trzech postów zostały one wyświetlone powyżej 10 tys. razy ${ }^{6}$, w przypadku 27 postów zanotowano od 2 tys. do 10 tys. odsłon; 28 filmów wyświetlono od 1 tys. do 2 tys. razy. Tysiąc razy i mniej obejrzano natomiast 56 filmów, tj. blisko połowę (por. Tabela 4).

Tabela 4. Liczba wyświetleń filmów opublikowanych na profilu TVP 3 Łódź

\begin{tabular}{|l|c|}
\hline \multicolumn{1}{|c|}{ Liczba wyświetleń } & Liczba filmów \\
\hline pow. 10 tys. & 3 \\
\hline 2 tys. -10 tys. & 27 \\
\hline 1 tys. -2 tys. & 28 \\
\hline 1 tys. i mniej & 56 \\
\hline Łączna liczba materiałów audiowizualnych & 114 \\
\hline
\end{tabular}

Źródło: opracowanie własne. Stan na 3.04.2018.

6 Były to materiały audiowizualne do postów z 8, 7 i 12 marca poświęconych: zbiórce pieniędzy dla chorego na nowotwór Kuby Gołębiowskiego, blokadzie drogi przez protestujących rolników, a także o propozycji zakazu sprzedaży alkoholu po godzinie 22 w Piotrkowie Trybunalskim. Ich liczba wyświetleń wyniosło (w kolejności): 62 903, 25801 i 20758 (stan na 3.04.2018). 
Cennym narzędziem w ocenie popularności treści wyrażanej za pośrednictwem publikowanych na omawianych profilach postów może być analiza kwartylowa. Z grupy postów zamieszczonych na Facebooku przez redakcję profilu „Expressu Ilustrowanego" $25 \%$ otrzymała jedynie do 8 polubień, połowa $\mathrm{z}$ nich zebrała 16, a $25 \%$ postów otrzymało co najmniej 34 kliknięcia „lubię to” (maksimum 381 ). W przypadku profilu Radia Łódź mediana liczby polubień wyniosła 3, co oznacza, że połowa postów miała mniej, a połowa - więcej polubień. $25 \%$ postów otrzymała 1 polubienie (lub nie otrzymała go wcale) i taka sama liczba - 8 i więcej kliknięć „lubię to" (maksimum 67). Podobne zachowania internautów można zauważyć w przypadku profilu TVP 3 Łódź. Mediana liczby polubień także wyniosła 3, natomiast $25 \%$ postów otrzymało 6 i więcej polubień (maksimum 93) (por. Tabela 5).

Tabela 5. Analiza kwartylowa liczby polubień postów

\begin{tabular}{|l|c|c|c|}
\cline { 2 - 4 } \multicolumn{1}{c|}{} & „Express Ilustrowany” & Radio Łódź & TVP 3 Łódź \\
\hline Minimum & 0 & 0 & 0 \\
\hline 1. & 8 & 1 & 1 \\
\hline 2. & 16 & 3 & 3 \\
\hline 3. & 34 & 8 & 6 \\
\hline Maksimum & 381 & 67 & 93 \\
\hline
\end{tabular}

Źródło: opracowanie własne. Stan na 3.04.2018.

Internauci rzadziej komentowali publikowane treści - najczęściej były one umieszczane na profilu „Expressu”, z tym że połowa postów otrzymała mniej, a połowa więcej niż 6 komentarzy, a jedynie jedna czwarta - 12 i więcej komentarzy (maksimum 299). Na profilu Radia Łódź 25\% postów uzupełniono co najmniej jednym komentarzem (maksimum 34 ). Analiza wykazała, że najrzadziej komentowane posty zamieszczano na profilu TVP 3 Łódź (por. Tabela 6).

Tabela 6. Analiza kwartylowa liczby komentarzy postów

\begin{tabular}{|l|c|c|c|}
\cline { 2 - 4 } \multicolumn{1}{c|}{} & „Express llustrowany" & Radio Łódź & TVP 3 Łódź \\
\hline Minimum & 0 & 0 & 0 \\
\hline 1. & 2 & 0 & 0 \\
\hline 2. & 6 & 0 & 0 \\
\hline 3. & 12 & 1 & 0 \\
\hline Maksimum & 299 & 34 & 10 \\
\hline
\end{tabular}

Źródło: oprac. własne. Stan na 3.04.2018. 
Najczęściej również udostępniano posty „Expressu”, połowa z nich była udostępniana 3 i więcej razy, ale $25 \%$ otrzymała 8 i więcej udostępnień (maksimum 143). Jedynie $25 \%$ postów Radia Łódź i TVP 3 Łódź zostało udostępnionych co najmniej raz; maksima również były niższe i wyniosły odpowiednio 11 i 91 razy (por. Tabela 7).

Tabela 7. Analiza kwartylowa liczby udostępnień postów

\begin{tabular}{|l|c|c|c|}
\cline { 2 - 4 } \multicolumn{1}{c|}{} & „Express Ilustrowany” & Radio Łódź & TVP 3 Łódź \\
\hline Minimum & 0 & 0 & 0 \\
\hline 1. & 1 & 0 & 0 \\
\hline 2. & 3 & 0 & 0 \\
\hline 3. & 8 & 1 & 1 \\
\hline Maksimum & 143 & 11 & 91 \\
\hline
\end{tabular}

Źródło: oprac. własne. Stan na 3.04.2018.

\section{Analiza jakościowa}

W wyniku analizy treści postów można stwierdzić, że redaktorzy każdego z trzech przebadanych profili społecznościowych publikowali informacje lokalne i regionalne, które dominowały w strukturze tematycznej wszystkich zamieszczanych postów.

Łącznie proporcjonalnie najwięcej postów o tematyce lokalnej i regionalnej ukazało się na profilu Radia Łódź i było to blisko 95\%, następnie na profilu TVP 3 Łódź (71,7\%) i w końcu na profilu „Expressu Ilustrowanego” - około 68\% (por. Tabela 8).

Tabela 8. Porównanie liczby postów o tematyce lokalnej i regionalnej do liczby wszystkich postów

\begin{tabular}{|l|c|c|c|}
\hline \multicolumn{1}{|c|}{ Liczba postów } & „Express llustrowany” & Radio Łódź & TVP 3 Łódź \\
\hline $\begin{array}{l}\text { Liczba postów o tematyce lokalnej } \\
\text { i regionalnej }\end{array}$ & 222 & 285 & 114 \\
\hline Liczba wszystkich postów & 327 & 302 & 159 \\
\hline Udział procentowy & $67,89 \%$ & $94,37 \%$ & $71,70 \%$ \\
\hline
\end{tabular}

Źródło: opracowanie własne. Stan na 3.04.2018. 
W przypadku postów „Expressu Ilustrowanego” tematyka lokalna dominowała; wiadomości z tego obszaru stanowiły $62 \%$ wszystkich postów. Stosunkowo dużo postów przyporządkowano do kategorii „rozrywka”. Co dziesiąta wiadomość poświęcona była tematyce krajowej, a 5\% dotyczyło regionu. Niewielki udział w grupie wszystkich postów miały zagadnienia zaklasyfikowane jako „inne”, „świat” i związane z tradycjami świątecznymi (por. Wykres 4).

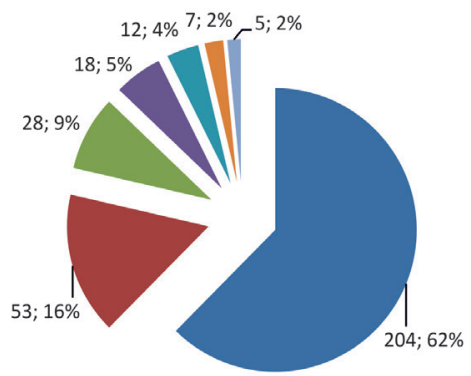

$$
\begin{aligned}
& \text { - Łódź (dalsze kategorie) } \\
& \text { - rozrywka } \\
& \text { - kraj (dalsze kategorie) } \\
& \text { - region (dalsze kategorie) } \\
& \text { च inne } \\
& \text { świat } \\
& \text { n tradycje świąteczne }
\end{aligned}
$$

Wykres 4. Tematyka opublikowanych postów na profilu Facebook „Expressu llustrowanego” (liczba; procent)

Źródło: opracowanie własne. Stan na 3.04.2018.

Przyglądając się bliżej postom o tematyce lokalnej, należy zauważyć, że w tej kategorii dominowały posty poświęcone wydarzeniom lokalnym (96 postów, tj. 47\% wszystkich postów o tematyce lokalnej). Sporo uwagi przywiązywano do postów tematycznie określonych jako „kronika policyjna” - obejmujących informacje na temat m.in. wypadków i innych zdarzeń losowych. Co dziesiąty post dotyczył wydarzeń sportowych odbywających się lokalnie, a 6\% - przepisów prawnych zakazujących handlu w niedzielę. Pozostałe przedstawione na wykresie 5 zagadnienia, określone jako zagadnienia lokalne, pojawiały się na profilu Facebook „Expressu Ilustrowanego" sporadycznie.

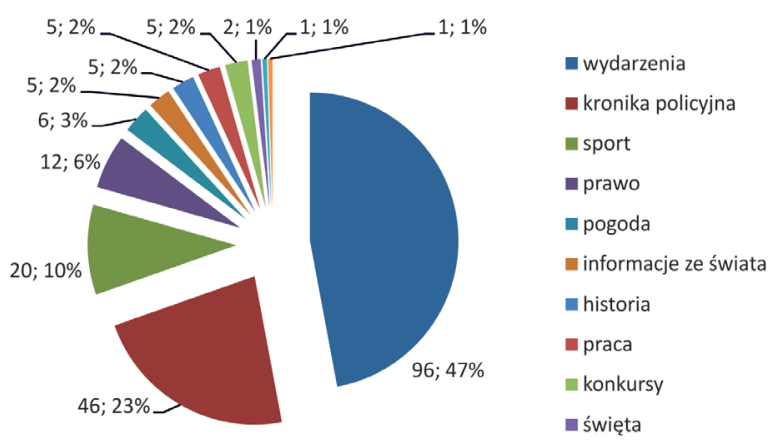

Wykres 5. Tematyka lokalna związana z Łodzią na profilu Facebook „Expressu Ilustrowanego” (liczba; procent)

Źródło: opracowanie własne. Stan na 3.04.2018. 
Tematyka regionalna była reprezentowana w badanych okresie przez 18 postów; dominowały wśród nich wydarzenia (blisko 3 na 4 posty regionalne) i kronika policyjna (por. Wykres 6).

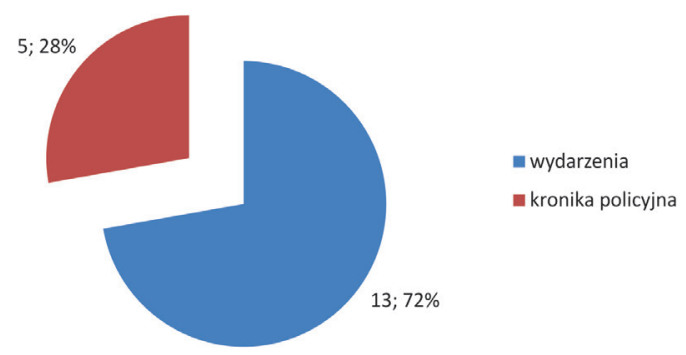

Wykres 6. Tematyka regionalna na profilu Facebook „Expressu Ilustrowanego” (liczba; procent) Źródło: opracowanie własne. Stan na 3.04.2018.

W 28 przypadkach publikowany na profilu „Expressu Ilustrowanego” post dotyczył tematyki krajowej - najczęściej wydarzeń ogólnopolskich (blisko połowa postów krajowych). W tej kategorii zaklasyfikowano również posty na temat pogody w kraju (29\% w kategorii), wydarzeń losowych (11\%), pracy (7\%) i prawa wprowadzającego zakaz handlu w niedziele (7\%) (por. Wykres 7).

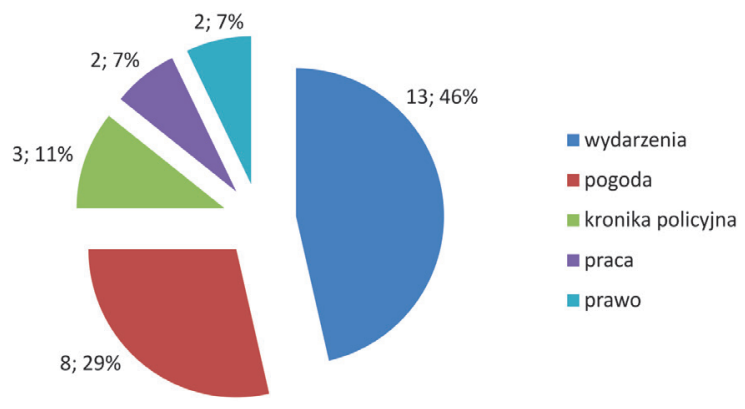

Wykres 7. Tematyka krajowa na profilu Facebook „Expressu llustrowanego” (liczba; procent) Źródło: opracowanie własne. Stan na 3.04.2018.

Wśród tematów postów opublikowanych na profilu Facebook Radia Łódź również dominowała tematyka lokalna i regionalna, stanowiąca łącznie $94 \%$ wszystkich postów. Mniej uwagi poświęcono tematyce określonej w badaniu kategoriami "zdrowie”, „rozrywka”, „tradycje świąteczne” (związane ze Świętami Wielkanocy), „świat” i „inne” (por. Wykres 8). 


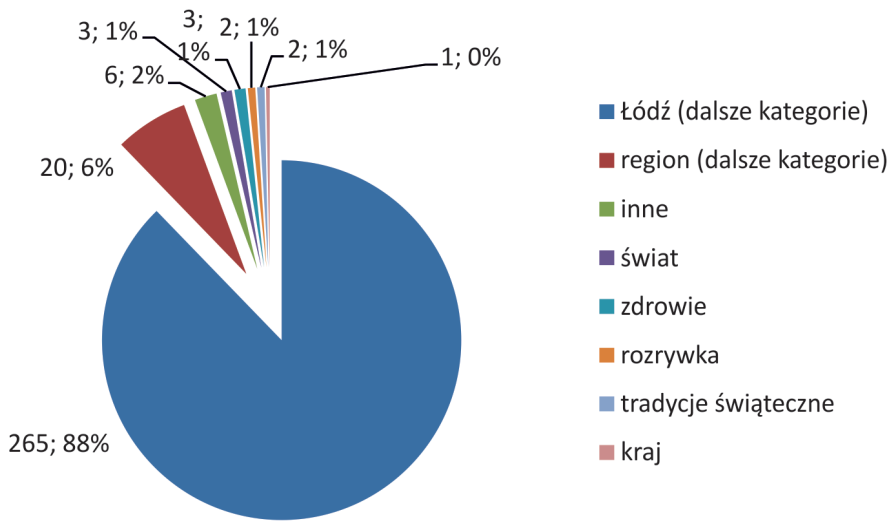

Wykres 8. Tematyka opublikowanych postów na profilu Radia Łódź (liczba; procent) Źródło: opracowanie własne. Stan na 3.04.2018.

Tematyka lokalna, poświęcona miastu, została zdominowana przez informacje o nadchodzących wydarzeniach (53\%). Co piąta wiadomość lokalna dotyczyła sportu, mniejszy udział miały wiadomości dotyczące planowanych na antenie radia rozmów (14\%) i audycji (10\%). Pozostała tematyka lokalna, w tym tematyka prawna związana $\mathrm{z}$ wprowadzonym po raz pierwszy w marcu zakazem handlu w wybrane niedziele, zamknęła się w liczbie $5 \%$ wszystkich wiadomości lokalnych (por. Wykres 9).

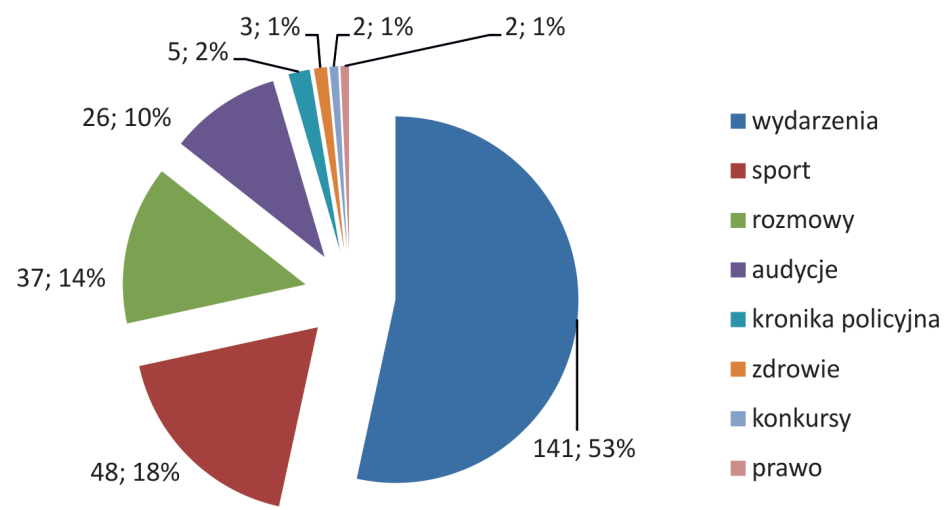

Wykres 9. Tematyka lokalna związana z Łodzią na profilu Facebook Radia Łódź (liczba; procent) Źródło: opracowanie własne. Stan na 3.04.2018.

Zagadnieniom regionalnym poświęcono niewiele miejsca; złożyło się na nie 20 postów, z których 18 informowało o wydarzeniach regionalnych, a po 1 - o wydarzeniach sportowych i z kroniki policyjnej (por. Wykres 10). 


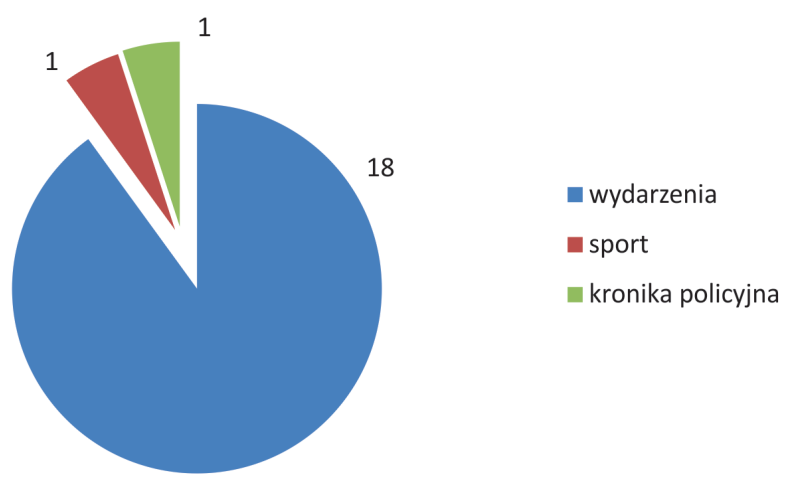

Wykres 10. Tematyka regionalna na profilu Facebook Radia Łódź (liczba; procent) Źródło: opracowanie własne. Stan na 3.04.2018.

W przypadku profilu TVP 3 Łódź tematyce lokalnej poświęcono blisko połowę zamieszczonych postów, a sprawom z regionu $-23 \%$. Tematy te stanowiły zatem większość zamieszczonych na profilu postów. Profil służył także informowaniu o programach i reportażach TVP 3 Łódź (łącznie 22\% postów). Pozostałe zagadnienia stanowiły $7 \%$ postów z marcową datą publikacji (por. Wykres 11).

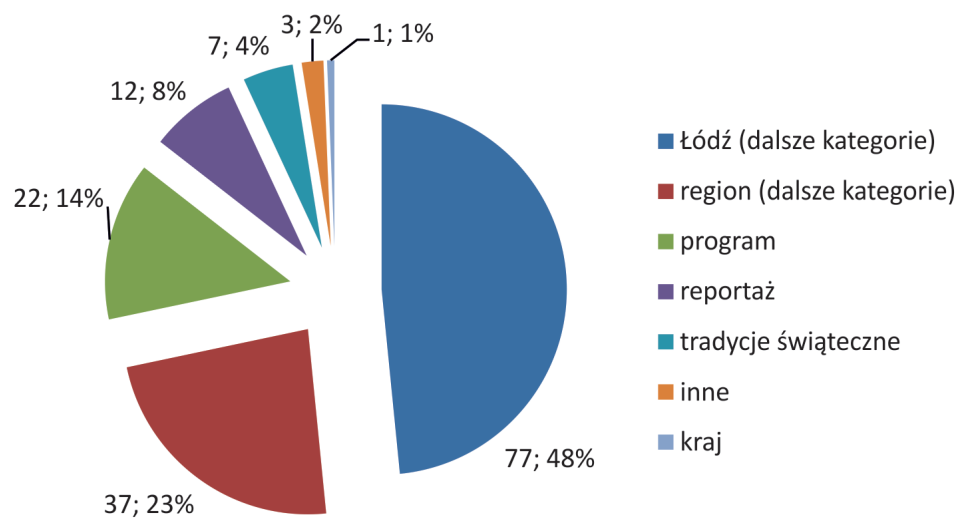

Wykres 11. Tematyka opublikowanych postów na profilu TVP 3 Łódź (liczba; procent) Źródło: opracowanie własne. Stan na 3.04.2018.

Zamieszczane na profilu posty o tematyce lokalnej najczęściej dotyczyły nadchodzących wydarzeń (86\%), a w przypadku $10 \%$ postów - zdarzeń określanych mianem kroniki policyjnej. Innym zagadnieniom poświęcono niewiele miejsca i nie przekroczyły one 4\% łącznej liczby postów o tematyce lokalnej (por. Wykres 12). 


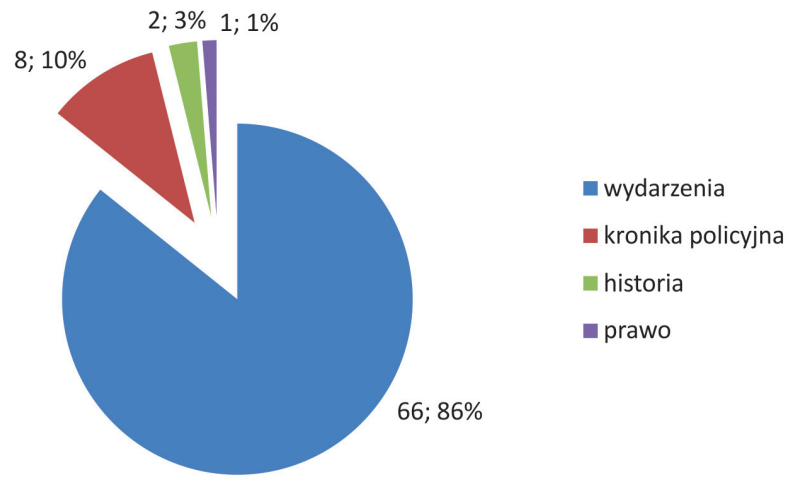

Wykres 12. Tematyka lokalna związana z Łodzią na profilu Facebook TVP 3 Łódź (liczba; procent) Źródło: opracowanie własne. Stan na 3.04.2018.

$\mathrm{Na}$ tematykę regionalną w przypadku profilu TVP 3 Łódź złożyły się dwa obszary, z których większościowy dotyczył wydarzeń regionalnych (prawie 90\% postów), a mniejszościowy (11\%) - zdarzeń z kroniki policyjnej (por. Wykres 13).

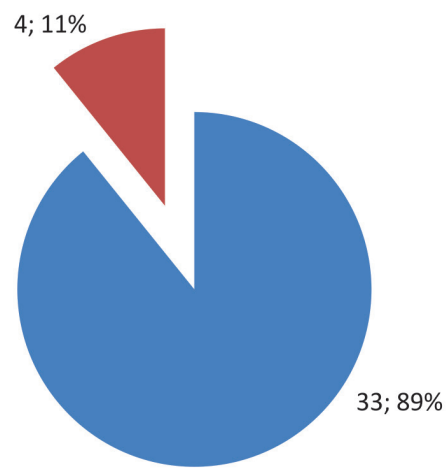

- wydarzenia

- kronika policyjna

Wykres 13. Tematyka regionalna na profilu Facebook TVP 3 Łódź (liczba; procent) Źródło: opracowanie własne. Stan na 3.04.2018.

Źródłem zdecydowanej większości publikowanych postów były internetowe strony główne poszczególnych mediów. Rzadziej były to posty własne. W przypadku portalu TVP 3 Łódź jego redaktorzy częściej publikowali posty z profilu Łódzkich Wiadomości Dnia - serwis Informacyjny TVP 3 Łódź niż ze strony internetowej www.lodz.tvp.pl. Zebrane dane dowodzą, że profile istotnie promują przede wszystkim media regionalne, rzadko udostępniając własne posty czy też informacje z innych źródeł (por. Wykres 14). 


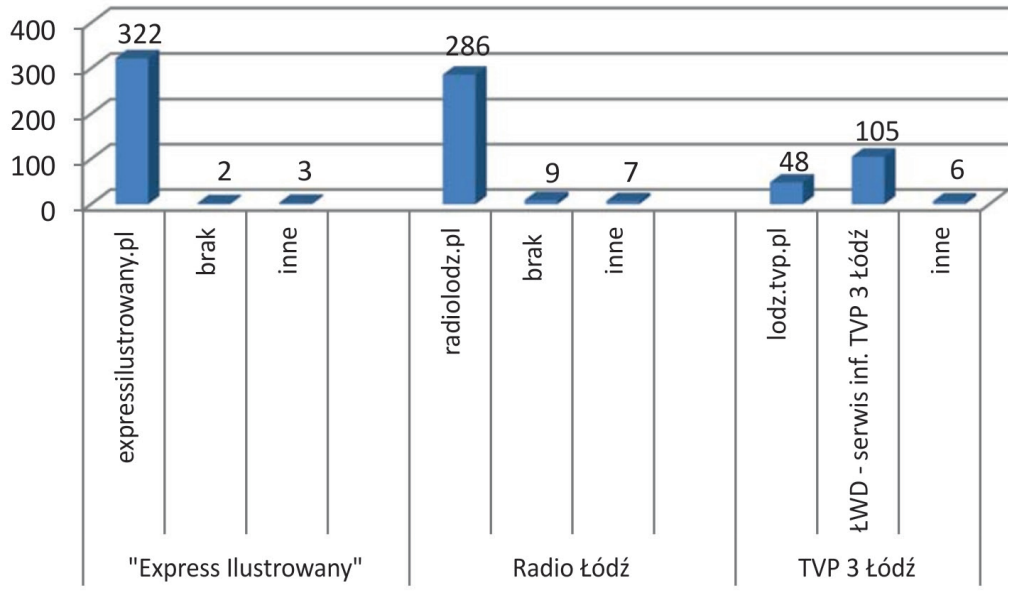

Wykres 14. Źródła informacji dla postów na profilu Facebook „Expressu llustrowanego”, Radia Łódź iTVP 3 Łódź

Źródło: opracowanie własne. Stan na 3.04.2018.

Spośród wszystkich trzech poddanych analizie profili internauci najczęściej reagowali za pośrednictwem kliknięcia przycisku „lubię to” w przypadku publikowanych wiadomości na temat wydarzeń losowych, sportu i informacji budzących emocje związanych $\mathrm{z}$ chorobą lub śmiercią. W zestawieniu umieszczonym w Tabeli 9 szeregującym posty pod względem liczby polubień widać, że w tej kategorii posty „Expressu Ilustrowanego” powodowały największą interakcję; wiadomości zawarte na profilach TVP 3 Łódź i Radia Łódź znalazły się dopiero na 18. i 34. miejscu. Liczba pozostawionych przez użytkowników polubień przy postach unaocznia dużą rozbieżność między skutecznością w dotarciu do odbiorcy.

Tabela 9. Zestawienie wybranych tytułów postów z największą liczbą polubień w badanym okresie

\begin{tabular}{|c|l|l|l|c|c|}
\hline Lp. & \multicolumn{1}{|c|}{ Tytuł posta } & \multicolumn{1}{|c|}{ Nazwa profilu } & Data & Godzina & $\begin{array}{c}\text { Liczba } \\
\text { polubień }\end{array}$ \\
\hline 1 & Śnieżyca w Łodzi & „Express Ilustrowany” & 17 marca & $08: 34$ & 381 \\
\hline 2 & Zmarł 6-letni Bartek Pawlak... & „Express llustrowany” & 21 marca & $13: 55$ & 361 \\
\hline 3 & Doping na Widzewie & „Express llustrowany” & 31 marca & $22: 37$ & 252 \\
\hline 18 & Historia 19-letniego Kuby... & TVP 3 Łódź & 20 marca & $19: 29$ & 93 \\
\hline 34 & $\begin{array}{l}\text { Adam Kszczot halowym } \\
\text { mistrzem świata }\end{array}$ & Radio Łódź & 3 marca & bd. & 67 \\
\hline
\end{tabular}

Źródło: opracowanie własne. Stan na 3.04.2018. 
W badanym okresie najwięcej komentarzy wywołały ponownie posty na profilu „Expressu Ilustrowanego”, a następnie Radia Łódź i TVP 3 Łódź - również związane $\mathrm{z}$ wydarzeniami losowymi, wprowadzoną niedzielą bez handlu, budzącym emocje internautów święceniem koszy wielkanocnych przed pawilonem handlowym czy planowanym zakazem nocnego handlu alkoholem. W zestawieniu trzy najczęściej komentowane posty opublikował „Express”, najczęściej komentowany post Radia Łódź znalazł się na 24,. a TVP 3 Łódź - na 109. miejscu. Ponownie daje się zaobserwować znaczne rozbieżności w zakresie liczby opublikowanych przez internautów komentarzy (por. Tabela 10).

Tabela 10. Zestawienie wybranych tytułów postów z największą liczbą komentarzy w badanym okresie

\begin{tabular}{|c|l|l|l|c|c|}
\hline Lp. & \multicolumn{1}{|c|}{ Tytuł posta } & \multicolumn{1}{|c|}{$\begin{array}{c}\text { Nazwa } \\
\text { profilu }\end{array}$} & Data & Godzina & $\begin{array}{c}\text { Liczba } \\
\text { komentarzy }\end{array}$ \\
\hline 1 & $\begin{array}{l}\text { Tak wczoraj wyglądał } \\
\text { Auchan w Manufakturze }\end{array}$ & $\begin{array}{l}\text { „Express } \\
\text { llustrowany” }\end{array}$ & 18 marca & $10: 25$ & 299 \\
\hline 2 & Przedszkole na medal & $\begin{array}{l}\text { „Express } \\
\text { "lustrowany” }\end{array}$ & 28 marca & $10: 03$ & 221 \\
\hline 3 & $\begin{array}{l}\text { Dlaczego w Łodzi } \\
\text { śmierdzi? }\end{array}$ & $\begin{array}{l}\text { „Express } \\
\text { llustrowany” }\end{array}$ & 10 marca & $21: 09$ & 202 \\
\hline 109 & $\begin{array}{l}\text { Święconka przed } \\
\text { pawilonem }\end{array}$ & Radio Łódź & 31 marca & $14: 16$ & 34 \\
& $\begin{array}{l}\text { Piotrków Trybunalski } \\
\text { może zostać pierwszym } \\
\text { miastem w województwie } \\
\text { tódzkim, w którym po } \\
\text { godz. 22 nie będzie można } \\
\text { kupić alkoholu }\end{array}$ & TVP 3 Łódź & 12 marca & $19: 27$ & 10 \\
\hline
\end{tabular}

Źródło: opracowanie własne. Stan na 3.04.2018.

Najliczniej udostępniane posty znów najczęściej publikowała redakcja profilu „Expressu”. Co jednak interesujące, czwartą pozycję w zestawieniu zajął post TVP 3 Łódź dotyczący choroby mieszkańca Koluszek. Najrzadziej posty, które były następnie udostępniane, publikowała redakcja profilu Radia Łódź (por. Tabela 11). 
Tabela 11. Zestawienie wybranych tytułów postów z największą liczbą udostępnień w badanym okresie

\begin{tabular}{|c|l|l|l|c|c|}
\hline Lp. & \multicolumn{1}{|c|}{ Tytuł posta } & $\begin{array}{c}\text { Nazwa } \\
\text { profilu }\end{array}$ & Data & Godzina & $\begin{array}{c}\text { Liczba } \\
\text { udostępnień }\end{array}$ \\
\hline 1 & $\begin{array}{r}\text { Ostrzelali ołowiem szkołę } \\
\text { w todzi }\end{array}$ & $\begin{array}{l}\text { „Express } \\
\text { Ilustrowany” }\end{array}$ & 14 marca & $19: 10$ & 143 \\
\hline 2 & $\begin{array}{l}\text { Dziecko w brzuchu mamy } \\
\text { zostało dłużnikiem ZUS }\end{array}$ & $\begin{array}{l}\text { „Express } \\
\text { Ilustrowany” }\end{array}$ & 22 marca & $16: 39$ & 95 \\
\hline 3 & Sensacyjne odkrycie & $\begin{array}{l}\text { „Express } \\
\text { llustrowany” }\end{array}$ & 28 marca & $17: 40$ & 95 \\
\hline 4 & Historia 19-letniego Kuby... & TVP 3 Łódź & 20 marca & $19: 29$ & 91 \\
\hline 70 & $\begin{array}{l}\text { W Strefie Młodych dziś } \\
\text { tłoczno }\end{array}$ & Radio Łódź & 22 marca & $18: 36$ & 11 \\
\hline
\end{tabular}

Źródło: opracowanie własne. Stan na 3.04.2018.

\section{Wnioski}

Wybrane do analizy profile społecznościowe trzech mediów lokalnych i regionalnych: „Expressu Ilustrowanego”, Radia Łódź i TVP 3 Łódź w istotny sposób promują tematykę regionalną, jednak formuła ich działalności różni się, przynosi więc też zróżnicowane efekty. Najlepiej w przestrzeni cyfrowej funkcjonuje profil „Expressu Ilustrowanego", czego dowodzi liczba kliknięć „lubię to”, komentarzy oraz udostępnień, a najgorzej - TVP 3 Łódź. Mimo że liczba opublikowanych postów „Expressu” i Radia Łódź jest zbliżona (w przypadku TVP 3 Łódź - o połowę mniejsza), jedynie redakcji „Expressu” udało się zbudować największą i najbardziej zaangażowaną społeczność wokół profilu, dzięki czemu publikowane w Internecie posty trafiają do największego kręgu odbiorów.

Przedstawione w treści artykułu dane i wnioski, choć dotyczą stosunkowo krótkiego, bo 31-dniowego okresu badania, mogą znaleźć zastosowanie w planowaniu zawartości adresowanych do społeczności lokalnych, bowiem prowadzą do sformułowania następujących tez:

1. Treści związane $\mathrm{z}$ emocjami generują większą liczbę polubień postów przez użytkowników niż inne publikowane treści.

2. Treści związane z wydarzeniami losowymi generują większą liczbę komentarzy użytkowników niż inne publikowane treści.

3. Treści sensacyjne generują większą liczbę udostępnień postów przez użytkowników niż inne publikowane treści. 
4. Największe zasięgi publikowanych treści buduje się przez zamieszczanie postów w godzinach popołudniowych i wieczornych (15:00-17:59; 18:0o-20:59).

5. Czynnikiem wpływającym na liczbę reakcji użytkowników jest głównie liczba osób, które polubiły stronę; pozyskiwanie odbiorców profilu jest zatem podstawowym czynnikiem warunkującym jego powodzenie.

Obecność i aktywność redakcji na Facebooku świadczy o tym, że portal ten jest widziany przed media regionalne jako płaszczyzna do promowania informacji lokalnych, jednak nie we wszystkich przypadkach był on w badanym okresie wykorzystywany na satysfakcjonującym poziomie.

\section{Bibliografia}

Bogdańska Jolanta, Między prasą a cyberprzestrzenią. Analiza porównawcza gazety i serwisu www na przykładzie „Dziennika Łódzkiego”, „Acta Universitatis Lodziensis. Folia Litteraria Polonica” 2016, nr 2(32), s. 149-165. https://doi. org/10.18778/1505-9057.32.12

Castells Manuel, Społeczeństwo sieci, przeł. M. Marody, Wydawnictwo Naukowe PWN, Warszawa 2008.

Kuczamer-Kłopotowska Sylwia, Rola mediów społecznościowych w komunikacji pokolenia Y, „Handel Wewnętrzny” 2016, nr 3(362), s. 216-227.

Łaszkiewicz Anna, Media społecznościowe i ich potencjał w generowaniu wartości dla organizacji, „Acta Universitatis Lodziensis. Folia Oeconomica” 2013, nr 287, s. $157-168$.

Smalec Agnieszka, Rola społeczności internetowych w komunikacji marketingowej, „Ekonomiczne Problemy Usług” 2010, nr 55, s. 579-588.

Stopczyńska Kinga, Zarządzanie wizerunkiem firmy przy wykorzystaniu Inbound marketingu na przykładzie fan page, „Acta Universitatis Lodziensis. Folia Oeconomica" 2013, nr 287, s. 181-191.

Wejs-Milewska Violetta, Współczesne radio - pytanie o tożsamość, „Acta Universitatis Lodziensis. Folia Litteraria Polonica” 2017, nr 1(39), s. 23-30. https://doi. org/10.18778/1505-9057.39.05

\section{Netografia}

Express Ilustrowany, https://www.facebook.com/ExpressIlustrowany/ [dostęp: 3.04.2018]. Radio Łódź, https://www.facebook.com/RadioLodz/ [dostęp: 3.04.2018].

TVP 3 Łódź, https://www.facebook.com/tvplodz/ [dostęp: 3.04.2018].

Zys Dorota, Inbound marketing - strategia przyszłości, https://sprawnymarketing.pl/ inbound-marketing-strategia-przyszlosci/ [dostęp: 27.04.2018]. 
Zbigniew Gruszka

\title{
Social Networking Sites as a tool to promote regional news: on the example of Facebook pages of 'TVP Łódź', 'Radio Łódž', and "Express Ilustrowany"
}

\author{
Summary
}

The author aims at evaluating the activities on the Facebook profiles of three regional media editorials - namely the 'TVP 3 Łódź' TV channel, the 'Radio Łódź radio channel, and the Express Ilustrowany daily - particularly in terms of including local and regional information in their posts. Another objective was to attempt to quantify and compare these activities. The used research method is the analysis of profile content on Facebook, and the study was conducted within the period of one month (1st March - 31st March, 2018).

Keywords: social media, regional information, promotion, social networking site

Zbigniew Gruszka, dr, adiunkt w Katedrze Informatologii i Bibliologii Uniwersytetu Łódzkiego. Zainteresowania naukowe: zarządzanie biblioteką, strategie biblioteczne, regionalistyka, digital literacy. Najważniejsze publikacje: Institutional Contexts of LIS Education in Poland, "Education for Information” 2020, t. 36, nr 4, s. 457-469; What May Library and Information Science Offer to Personal Information Management? "Zagadnienia Informacji Naukowej” 2020, nr 2, s. 40-55; Deregulation of the librarian profession in Poland: the course and the consequences (współautor M. Antczak), [w:] Information and technology transforming lives: connection, interaction, innovation: Proceedings of International Symposium Bobcatsss, Osijek 2019, s. 23-40. 